This item was submitted to Loughborough's Research Repository by the author.

Items in Figshare are protected by copyright, with all rights reserved, unless otherwise indicated.

\title{
Simplest Prussian-blue deposition from ferric ferricyanide solution by a reducing Ag spot put onto an ITO substrate
}

\section{PLEASE CITE THE PUBLISHED VERSION}

http://dx.doi.org/10.1007/s10008-012-1811-7

PUBLISHER

(C) Springer-Verlag

VERSION

AM (Accepted Manuscript)

LICENCE

CC BY-NC-ND 4.0

\section{REPOSITORY RECORD}

Barton, Ray T., Hassan Kellawi, Frank Marken, Roger J. Mortimer, and David R. Rosseinsky. 2019. "Simplest Prussian-blue Deposition from Ferric Ferricyanide Solution by a Reducing Ag Spot Put onto an ITO Substrate". figshare. https://hdl.handle.net/2134/11417. 
This item was submitted to Loughborough's Institutional Repository (https://dspace.lboro.ac.uk/) by the author and is made available under the following Creative Commons Licence conditions.

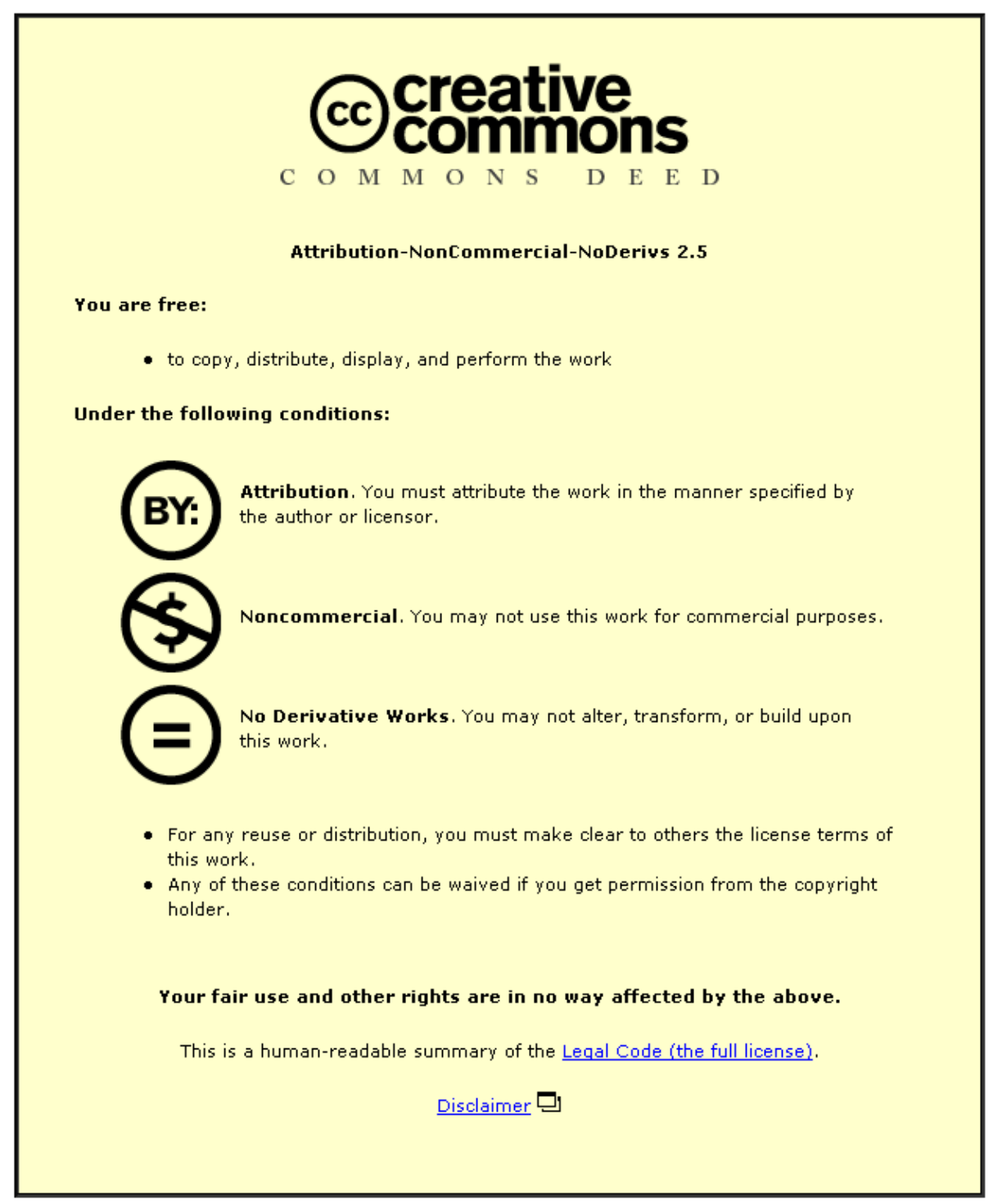

For the full text of this licence, please go to: http://creativecommons.org/licenses/by-nc-nd/2.5/ 


\title{
Simplest Prussian-blue deposition from ferric ferricyanide solution by a reducing Ag spot put onto an ITO substrate
}

Ray T Barton • Hassan Kellawi • Frank Marken • Roger J Mortimer • David R Rosseinsky

\begin{abstract}
Prussian blue (PB) film for electrochromism can be electro-deposited on to an electrode [usually tin-doped indium oxide /glass ] either directly from a PB colloid, or from ferric ferricyanide in a two-electrode electrochemical cell by applying a reductive potential. Alternatively, a "sacrificial” electron-producing silver flag electrode in the solution, when connected to the PB-receiving electrode, can effect the required reductive deposition. A silver spot, here innovatively applied as silver paint directly onto the deposition electrode, produces PB film on immersion in the iron(III)(III) solution, obviating the separate counterelectrode method.
\end{abstract}

Key words: Prussian blue, thin films, silver, electrochromic

R. T. Barton • R. J. Mortimer

Department of Chemistry, Loughborough University,

Loughborough, Leicestershire LE11 3TU, UK

H. Kellawi

Department of Chemistry, The University of Damascus,

Damascus

Syria

F. Marken

Department of Chemistry, The University of Bath,

Claverton Down

Bath BA2 7AY, UK

D. R. Rosseinsky (*)

School of Physics

The University of Exeter

Exeter EX4 4QL, UK

email: d.r.rosseinsky@ex.ac.uk 


\section{Introduction}

Prussian Blue (PB), “ferric ferrocyanide”, comprises a widely-used group of materials [1] $\mathrm{M}^{+} \mathrm{Fe}^{3+} \mathrm{Fe}^{\mathrm{II}}(\mathrm{CN})_{6}$ where $\mathrm{M}$ can be any alkali cation (or $1 / 3 \mathrm{Fe}^{3+}$ in the "insoluble $\mathrm{PB}$ " form). In historical and current use as a pigment [2], the colouration arises from the optical chargetransfer between the $\mathrm{Fe}^{\mathrm{II}}$ and the $\mathrm{Fe}^{3+}$. In recent decades Neff [3, 4] showed $\mathrm{PB}$ to be an electrochrome [1] of extensive applicability, as recently exemplified [5]. The PB electrochromic reaction, via externally-applied electrochemistry, is basically $\mathrm{Fe}^{3+} \mathrm{Fe}^{\mathrm{II}}(\mathrm{CN})_{6}[\mathrm{~PB}$, blue $]+\mathrm{e}^{-} \rightarrow \mathrm{Fe}^{2+} \mathrm{Fe}^{\mathrm{II}}(\mathrm{CN})_{6}[$ clear $]$ where the reduced, clear, form is "Prussian White" (PW) [1] . The substrate is commonly transparent tin-doped indium oxide (ITO)/glass.

For PB electrochromism there are two main methods of preparation. Commonly, electrodeposition (electrochemical reduction) from ferric ferricyanide solution, on to transparent conductive ITO/glass, is effected by an applied external potential [1] (note that Neff [3, 4] just immersed a pre-cathodised Pt or Au surface for the required reduction). Alternatively, colloidal PB has been directly electrodeposited straight onto the receiving electrode [6]. Ho $[7,8]$ introduced a variation of the former by using a separate silver metal electrode connected directly to the ITO also immersed in the iron(III)(III) deposition solution: sacrificial Ag dissolution causes reductive deposition of PB via the Ag-liberated electrons. Here, we describe the use of a silver metal spot directly applied to the ITO/glass, which, on total immersion of the assembly into the iron(III)(III) solution, undergoes just that sacrificialsilver reaction to produce a uniform PB film. This dispenses with the need of an electrochemical cell and a separate stand-alone Ag metal electrode. The Ag spot comprises silver paint as is commonly used to make external electrical connections to electrodes. 


\section{Experimental}

Two sizes of ITO-coated glass ( Image Optics Components Ltd., Basildon, Essex, typically $20 \Omega$ per square), were used, either $0.9 \times 5.5 \mathrm{~cm}^{2}$ (the lower $0.9 \times 4.0 \mathrm{~cm}^{2}$ area is immersed in solution in electrochromic operation), or for larger electrodes, $20 \mathrm{x} 25 \mathrm{~cm}^{2}$ (1.5 cm protruding atop in electrochromic use). The ITO/glass pre-cleaned in ethanol was sonicated in aqueous detergent for $c a 1 \mathrm{~h}$, well washed with tap water then de-ionised water (nominal 18.2 M $\Omega \mathrm{cm}$ ). When dry a small spot of E1660-136 silver ink (a suspension of finely divided silver in a resin, from Ercon Inc., Wareham, MA, USA) was applied with a Pasteur pipette to give a thin spot of area $\sim 0.04 \mathrm{~cm}^{2}$ onto a corner of the ITO/glass electrode. This Ag-spot ITO/glass was oven-dried for $1 \mathrm{~h}$ then cooled over silica gel.

The PB deposition bath comprised $0.002 \mathrm{~mol} \mathrm{dm}^{-3} \mathrm{~K}_{3} \mathrm{Fe}(\mathrm{CN})_{6}$ (BDH AnalaR) with $\mathrm{HCl}$ to $\mathrm{pH} \sim 3-4$, followed by slow addition with vigorous stirring of either solid $\mathrm{FeCl}_{3} \cdot 6 \mathrm{H}_{2} \mathrm{O}$ or $\mathrm{Fe}\left(\mathrm{NO}_{3}\right)_{3} \cdot 6 \mathrm{H}_{2} \mathrm{O}$ (both Fisher Scientific for analysis) to $0.002 \mathrm{~mol} \mathrm{dm}^{-3}$; the $\mathrm{pH}$ avoided hydrolysis of the $\mathrm{Fe}^{3+}(\mathrm{aq})$. The resultant $\mathrm{Fe}^{3+} \mathrm{Fe}^{\mathrm{III}}(\mathrm{CN})_{6}$ complex is light brown in solution..

On immersion of the ITO/glass in the iron(III)(III) solution, the PB-forming reaction takes several minutes to deposit a uniform film on the smaller electrode. On the large electrode the deposition took several hours. Lighter PB deposits result by removing the Ag/ITO-glass/PB assembly from the deposition solution sooner. The PB films were well washed with DI water, drip-dried then kept in a desiccator over blue silica gel for reproducible $\mathrm{H}_{2} \mathrm{O}$ content.

For electrochromism, the PB/ITO-glass electrode is immersed in an appropriate electrolyte-containing cell with a second, counter, electrode [1]. The preparative Ag spot is isolated here with say silicone cement if not employed as part of the external connection that is isolated from the echrome-cell electrolyte. This can be $\mathrm{KCl}$ solution [1] or an ionically conductive polymer [5]. 
Well- rehearsed in the literature e.g. [6], the widened CVs of thick PB ( between ca $-0.3 \mathrm{~V}$ and $+0.3 \mathrm{~V}$ vs the calomel electrode) are as previously recorded [1], while thin-film PB traces conform with the corresponding published CVs [9]. Ag-deposited PB is more uniform than ordinarily electrodeposited PB especially for large areas [7, 8], undergoing the on/off echrome reactions $\mathrm{PB}+\mathrm{e}^{-} \rightleftarrows \mathrm{PW}$ with satisfactory uniformity.

\section{Discussion}

A novel shortcut to PB electrodeposition, that employs just a single ITO substrate in the place of a preparative electrochemical cell, has been established here in a modified "sacrificial Ag anode” method, by using a silver spot deposited directly onto the PB-receiving electrode. The solution concentrations were not especially critical, as for example the ferric ferricyanide concentration when halved had no deleterious effect, only slowing the deposition. Faster deposition ensues with extra deposited Ag spots (alongside the original, to avoid subsequently insulated blots in the electrochromic area). Liberated $\mathrm{Ag}^{+}$will complex with deposition- solution species. The quality of deposited PB is entirely satisfactory (our trial Ag-flag deposited PB being initially less adherent, perhaps from poor deposition-cell geometry). In later experiments (McPhaden L, personal communication), ageing the original $\mathrm{Fe}(\mathrm{III})(\mathrm{III})$ solution in daylight for $\geq 48 \mathrm{~h}$ partly reduced the original solution to green, a well-known state [1], by photo-reaction with $\mathrm{H}_{2} \mathrm{O}$. The Ag-driven PB deposition was hereby markedly accelerated, a subject of ongoing research. The Ag spot method was foreseen in an early study $[1,10]$.

A just-published preparation [11] of a fine Ag network on glass, that is almost completely transparent and conductive ( $1 \Omega$ per square), promises highly uniform PB deposition by our method. Enough residual Ag might provide a conduction system free of ITO.

\section{Acknowledgements}

H K acknowledges leave from Damascus University. 


\section{References}

1. Monk PMS, Mortimer RJ, Rosseinsky DR (2007) Electrochromism and Electrochromic Devices. Cambridge University Press, Cambridge. Chapter 8

2. Kirby J, Saunders D (2004) National Gallery Technical Report, London 25:73-99

3. Neff V D (1978) J Electrochem Soc 125:886-887

4. Ellis D, Eckhoff M, Neff VD (1981) J Phys Chem 85:1225-1231

5. Soutar AM, Rosseinsky DR, Freeman W, Zhang X, How X, Jiang HJ, Zeng XT, Miao X (2012) Sol Energy Mater Sol Cells 100:268-270

6. Cisternas R, Muñoz E, Henríquez R, Córdova R, Kahlert H, Hasse U, Scholz F (2011) J Solid State Electrochem 15:2461-2468

7. Ho KC (1994 Proc Electrochem Soc, 94:170-171

8. Ho KC(1999). Electrochim. Acta 44: 3227-3235

9. Rosseinsky DR, Glidle A (2003) J Electrochem Soc 150: C641-C645

10. Kellawi H, Rosseinsky D (1982) J Electroanal Chem 131:373-376

11. Shin D-Y, Jung M, Chun S (2012) J Mater Chem 22:11755-11764 